\title{
Barbara Sztokfisz
}

Cracow University of Economics

e-mail: barbara.sztokfisz@gmail.com

ORCID: 0000-0002-5615-7571

\section{DIFFUSION OF INNOVATIONS IN DEVELOPING COUNTRIES: BLOCKCHAIN CASE STUDY}

\section{DYFUZJA INNOWACJI DO KRAJÓW \\ ROZWIJAJĄCYCH SIĘ: STUDIUM PRZYPADKU TECHNOLOGII BLOCKCHAIN}

DOI: $10.15611 / \mathrm{e} 21.2019 .1 .04$

JEL Classification: O33, F63, I30

Summary: Distributed Ledger Technologies (DLTs) have become a topic that is being more and more discussed in political, economic and scientific discourses. , also within economic sciences. Their potential to redefine many processes in the economy is growing, and there is a consensus in the scientific community about their revolutionary character. Blockchain is one of the DLTs and one of the breakthrough technologies distinctive for the Fourth Industrial Revolution. The aim of the paper is to draw attention to the potential of blockchain technology for developing countries and how it can contribute to the improvement of quality of life and fighting poverty. Following Schwab's thesis, "the extent to which society embraces technological innovation is a major determinant of progress". Therefore, developing countries should not disregard the potential of blockchain technology that can solve a lot of current problems and provide access to previously unreachable services with a relatively low cost (both implementation and subsequent maintenance cost).

Keywords: blockchain, distributed ledger technology, developing countries, economic growth, diffusion of innovations.

Streszczenie: Algorytmy umożliwiające tworzenie rozproszonych rejestrów (Distributed Ledger Technologies, DLT) stanowią obecnie temat coraz częściej poruszany w dyskursach politycznych, gospodarczych oraz naukowych, także w obrębie nauk ekonomicznych. Ich potencjał do zredefiniowania wielu procesów w gospodarce zaczyna być coraz bardziej dostrzegany, a w środowisku naukowym panuje konsensus co do ich rewolucyjnego charakteru. Blockchain stanowi jedną z technologii rozproszonych rejestrów oraz jedną z przełomowych technologii charakterystycznych dla czwartej rewolucji przemysłowej. Jego pojawienie się bywa utożsamiane $\mathrm{z}$ wkroczeniem do drugiej ery Internetu. Celem artykułu jest zwrócenie uwagi na potencjał, jaki technologia blockchain może mieć dla krajów rozwijających się, i na to, w jaki sposób może się przyczynić do poprawy jakości życia ich ludności oraz do walki z ubóstwem. Za twierdzeniem K. Schwaba, zauważa się, że jest to właśnie „stopień, w jakim kraje są w stanie przyjąć i zaimplementować nowe technologie jest główną determinantą ich 
postępu". Technologiczna innowacja jest często postrzegana jako kluczowy czynnik długookresowego wzrostu gospodarczego, nie budzi więc wątpliwości fakt, że coraz większa liczba naukowców oraz ekspertów porusza ten temat i stara się odpowiedzieć na pytanie, w jaki sposób technologie cyfrowe mogą pomóc zwalczać ubóstwo i stać się czynnikiem poprawiającym poziom życia ludności. O ile państwa rozwinięte szybko implementują pojawiające się rozwiązania i potrafią je wykorzystać do poprawy życia ludności oraz wzrostu i rozwoju gospodarczego, o tyle w krajach rozwijających się nie jest to zjawisko powszechne. Większość najnowszych osiągnięć nauki pojawia się w krajach rozwiniętych, co jeszcze bardziej przyczynia się do ich nierównomiernego rozprzestrzeniania się innowacyjnych technologii, zostawiając w tyle najbiedniejsze państwa. Dlatego tak istotne jest, aby we wspieraniu rozwoju i dobrobytu krajów rozwijających się obecne były transfer technologii oraz związany z nią know-how. Kraje rozwijające się nie powinny lekceważyć potencjału technologii blockchain ani nie wykorzystać szansy, dzięki której mogą stosunkowo niskim nakładem kosztów (zarówno implementacji, jak i późniejszego utrzymania) rozwiązać wiele aktualnych problemów oraz zapewnić dostęp do wcześniej nieosiągalnych usług.

Słowa kluczowe: blockchain, technologia rozproszonego rejestru, kraje rozwijające się, wzrost gospodarczy, dyfuzja innowacji.

\section{Introduction}

Distributed Ledger Technologies (DLTs) have recently gained considerable attention and have become a topic discussed in political, economic and scientific discourses, included within economic sciences. Their potential to redefine many processes in economies is growing. There is a broad consensus among the scientific community about their revolutionary character. Blockchain is one of the DLTs and one of the breakthrough technologies that are distinctive for the Fourth Industrial Revolution [Schwab 2017]. Its appearance is identified with the entry to the second Internet era [Tapscott, Tapscott 2016]. Governments ${ }^{1}$, international organizations ${ }^{2}$, banks [Kelly 2017] and individual researchers ${ }^{3}$ are currently investigating the potential of the blockchain technology for our economies. What is more, the World Economic Forum placed blockchain third on the list of the Top 10 Emerging Technologies 2016 [World Economic Forum Global Agenda].

${ }^{1}$ The pioneer among European countries when it comes to the use of Distributed Ledger Technologies is Estonia, which has been developing new and safer solutions based on blockchain technology for several years. Estonians currently use the majority of public services via the Internet [Korjus 2017].

${ }^{2}$ The European Commission set up an EU Blockchain Observatory to monitor the development of this technology, its potential for the economy and to map key initiatives [EU Blockchain Observatory and Forum ]. In addition, the European Parliament is working on a new legislation on Blockchain Resolution on Distributed Ledger Technologies and Blockchains: Building Trust with Disintermediation [European Parliament].

${ }^{3}$ Tapscott D. and Tapscott A. [2016]; Swan [2015]; Pilkington [2015]; Klinger and Szczepański [2017]; Pisa and Juden [2017]; Rosati et al. [2016] and many others. 
The aim of this paper is to analyse the potential that blockchain technology can have for developing countries and how it can contribute to the improvement of quality of life and fighting poverty. Following K. Schwab's thesis, "the extent to which society embraces technological innovation is a major determinant of progress" [Schwab 2017]. Because technological innovation is often perceived as a key factor in long-term economic growth, there is no doubt that an increasing number of scientists and experts are leaning on this topic and attempting to answer the question of how digital technologies can help fight poverty and become a factor improving the conditions of life of populations [Pisa, Juden 2017].

\section{Structure and methodology}

The structure of this paper is as follows. Firstly, the basics of blockchain technology, its main assumptions, primary areas of implementation and advantages and disadvantages are explained. Secondly, attention is focused on the diffusion of innovation (based on E. Rodgers's theory), as well as on the key determinants of innovation. Thirdly, the aspect of technological change and uncertainty with examples and references to the Fourth Industrial Revolution (based on N. Rosenberg's postulates) is presented. Finally, areas where blockchain technology can improve certain processes and contribute to an effective fight against poverty in developing countries are given.

The methodology of the article is based mainly on the analysis of existing solutions that use blockchain technology. The basic assumptions of this technology as well as the issues of the poorest countries lead to the conclusion that many of such countries can benefit from blockchain. The methodology also involves the analysis of the opinions of international organisations, governments and private sector representatives. Three areas where blockchain technology can be important in improving the quality of life and combating poverty in developing countries have been established: (1) the financial sector, (2) protection of property rights, (3) humanitarian aid. These are also the areas where specific solutions and projects have already started to appear.

\section{How does blockchain work?}

The concept of blockchain technology was designed in 2008 by an anonymous scientist (or group of scientists) under the pseudonym Satoshi Nakamoto and published in the form of a white paper entitled "Bitcoin: A Peer-to-Peer Electronic Cash System" [Nakamoto 2008]. Its history is linked with the currently most popular cryptocurrency, bitcoin, capitalised at its peak at over USD 320 billion, with the price for one bitcoin reaching almost USD 20,000 [Internet Users in Africa]. Blockchain has been designed as an electronic payment system that allows parties to make transactions directly with each other without an intermediary. It does not have a central body and is based on 
a consensus created thanks to the decentralised nature of the Internet [Nakamoto 2008]. The diagram below shows a traditional, centralised approach and a decentralised approach based on the blockchain technology.
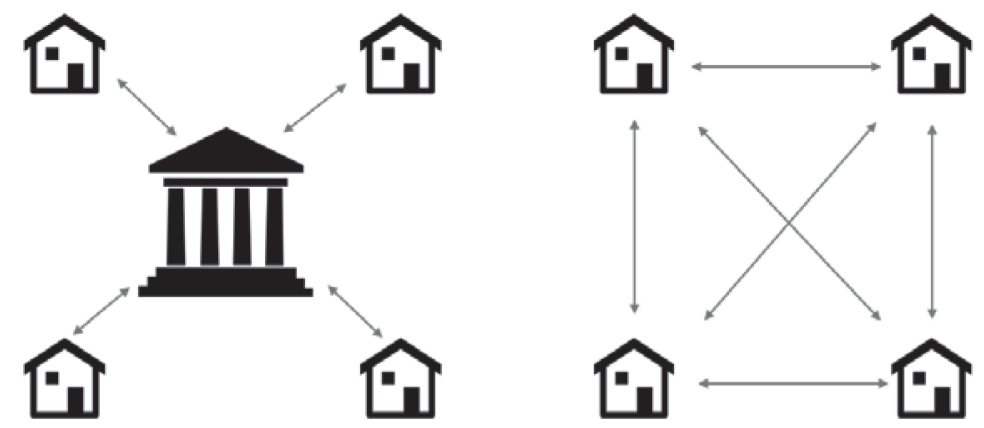

Fig. 1. Centralisation vs. decentralisation

Source: own elaboration.

Moreover, all transactions in the blockchain network are public for each network user. The diagram below shows the traditional financial model, where only a trusted third party has access to information, and a new model, where all transactions are public, while the disclosure of identities remains optional.

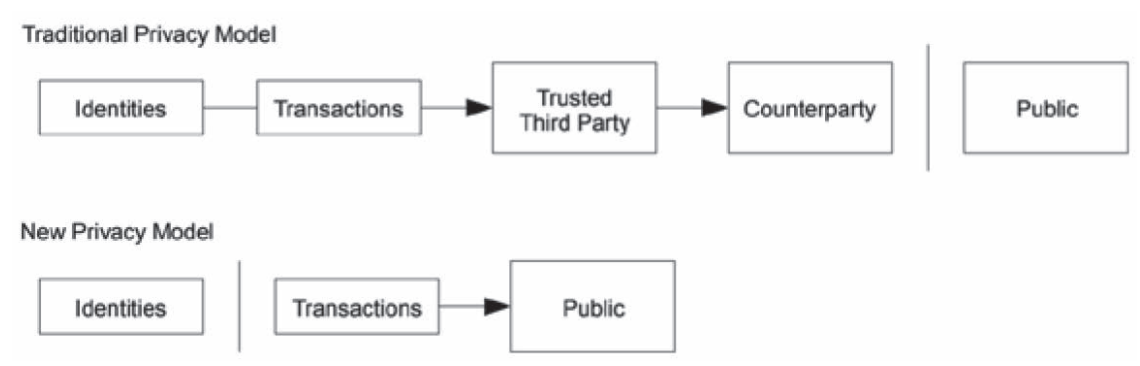

Fig. 2. Privacy in the traditional model and a blockchain-based model

Source: [Nakamoto 2008].

Interest in blockchain technology has led to its escalation to other areas of the economy. Its functional possibilities are much wider and go well beyond the financial sector. Cryptocurrencies are only one of the areas of its application. There are also more and more voices that the main obstacles related to the development of the blockchain technology and the implementation of solutions are not technological in character, but are instead related to legal and regulatory aspects [Pisa, Juden 2017]. The last two remain the main challenges of the Fourth Industrial Revolution and will 
affect the diffusion of new technologies [Schwab 2017]. According to M. Iansiti and K. Lakhani [2017], the real transformation connected with the implementation of blockchain technology will happen in many years due to the fact that this technology is so ground-breaking that it will not only redefine the existing business models, but will also become the foundation for completely new solutions within the existing social and economic system ${ }^{4}$.

Table 1. Advantages of and challenges for the blockchain technology

\begin{tabular}{|l|l|}
\hline \multicolumn{1}{|c|}{ Advantages } & \multicolumn{1}{|c|}{ Challenges } \\
\hline $\begin{array}{l}\text { - } \text { reduced transaction costs } \\
\text { faster transfers }\end{array}$ & $\begin{array}{l}\text { - high energy costs } \\
\text { - } \text { lack of regulation } \\
\text { available) }\end{array}$ \\
$\begin{array}{l}\text { - lack of a single point of failure } \\
\text { high level of security thanks to cryptographic } \\
\text { mechanisms }\end{array}$ & $\begin{array}{l}\text { collection) } \\
\text { early stage of technological development } \\
\text { anonymity and privacy }\end{array}$ \\
\hline
\end{tabular}

Source: own analysis based on [Pisa Juden 2017; Rosati et al. 2016; Iansiti Lakhani 2017; Schwab 2017; Zheng et al. 2017].

Blockchain is a decentralised and distributed ledger, where data is grouped into blocks and then linked to the chain. The chain contains a record of all data and any modification made from the very beginning. Cryptographic mechanisms and the proof-of-work principle mean that once encrypted, data cannot, in principle, be unnoticed [Pisa, Juden 2017]. Blockchain eliminates the need for an intermediary who would guarantee the credibility of the transaction. Trust is replaced by cryptographic evidence [Nakamoto 2008]. It allows a direct transaction between persons who do not know each other and therefore have no reason to trust each other [Schwab 2017; Tapscott, Tapscott 2016].

There are many areas in which blockchain has the potential to redefine current mechanisms and processes. The most frequently explored areas are:

- Finance: cryptocurrencies and services within the banking sector [Swan 2015].

- Logistics: supply chain tracking [Pilkington 2015].

- Trade: confirmation of the authenticity of goods [Klinger, Szczepański 2017].

- Protection of property rights [Pisa, Juden 2017].

- Digital identity [Pilkington 2015].

- Electronic voting systems [Pilkington 2015].

It is also worth presenting the main advantages and challenges of blockchain technology. One of its features, anonymity and privacy, fits both categories, as it can have a strong negative and positive impact.

\footnotetext{
${ }^{4}$ This thesis is also justified by N. Rosenberg's postulate [1996] that the most ground-breaking technologies are not substitutes for already existing ones (e.g. laser or electricity).
} 


\section{Conceptual basis of the diffusion of innovations}

While developed countries quickly implement emerging solutions and are able to use them to improve people's lives as well as to boost economic growth and development, this phenomenon does not occur in developing countries. Most of the latest scientific achievements are implemented in developed countries, which further contributes to their uneven spread, leaving the poorest countries behind. That is why it is so important that the transfer of technologies and the related know-how be present to support the growth and prosperity of developing countries. The assertion that the diffusion of technology for developing countries is significantly prolonged is justified by the statement that electricity (the output of the Second Industrial Revolution started at the end of the nineteenth century) is fully used by only $17 \%$ of the world's population, and as many as 1.3 billion still experience its complete lack. The same is true for the Third Industrial Revolution and the emergence of the Internet, which is not yet accessible to 4 billion people [Schwab 2017]. The following charts illustrate these facts.

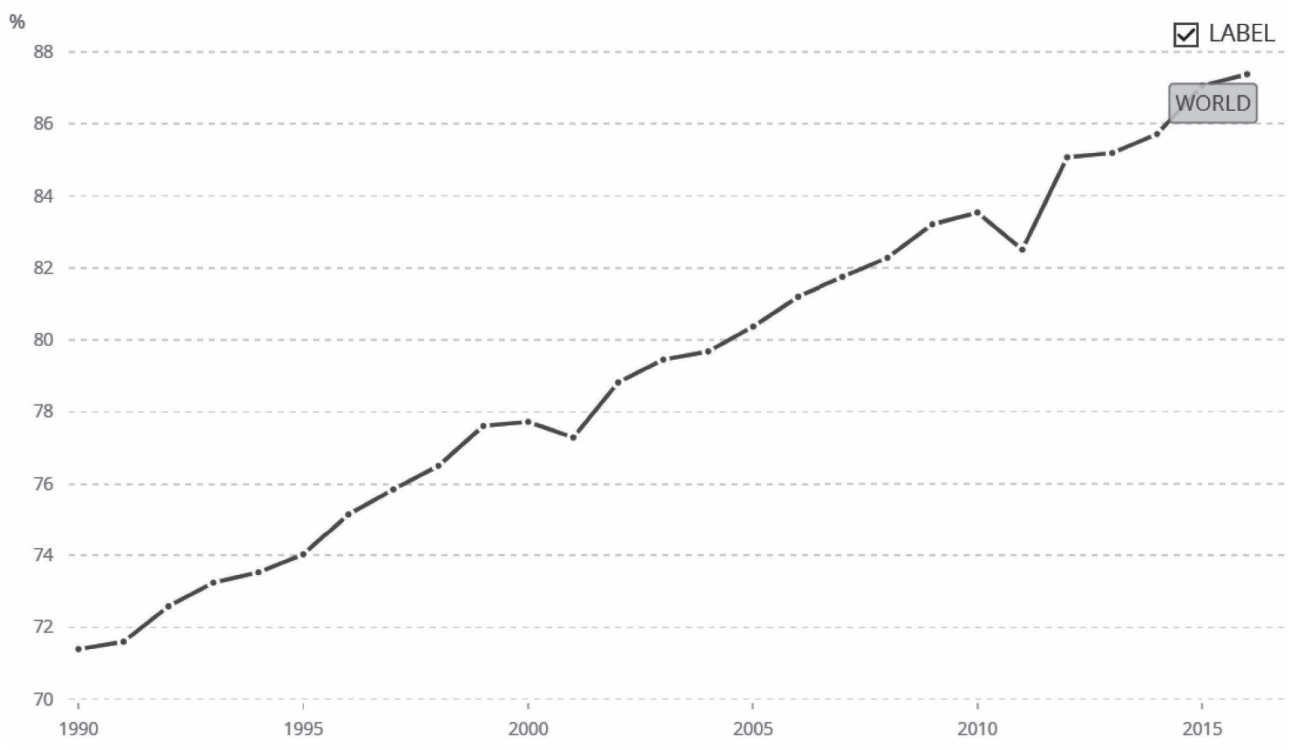

Fig. 3. Access to electricity ( $\%$ of population)

Source: [World Bank Data (a)].

The theory of the diffusion of innovation explains why and how new ideas spread and how they are adopted. E. Rodgers defines the term diffusion of innovation as a process in which innovation is communicated to the members of the social system through certain channels. The main aspects that have the greatest impact on this 


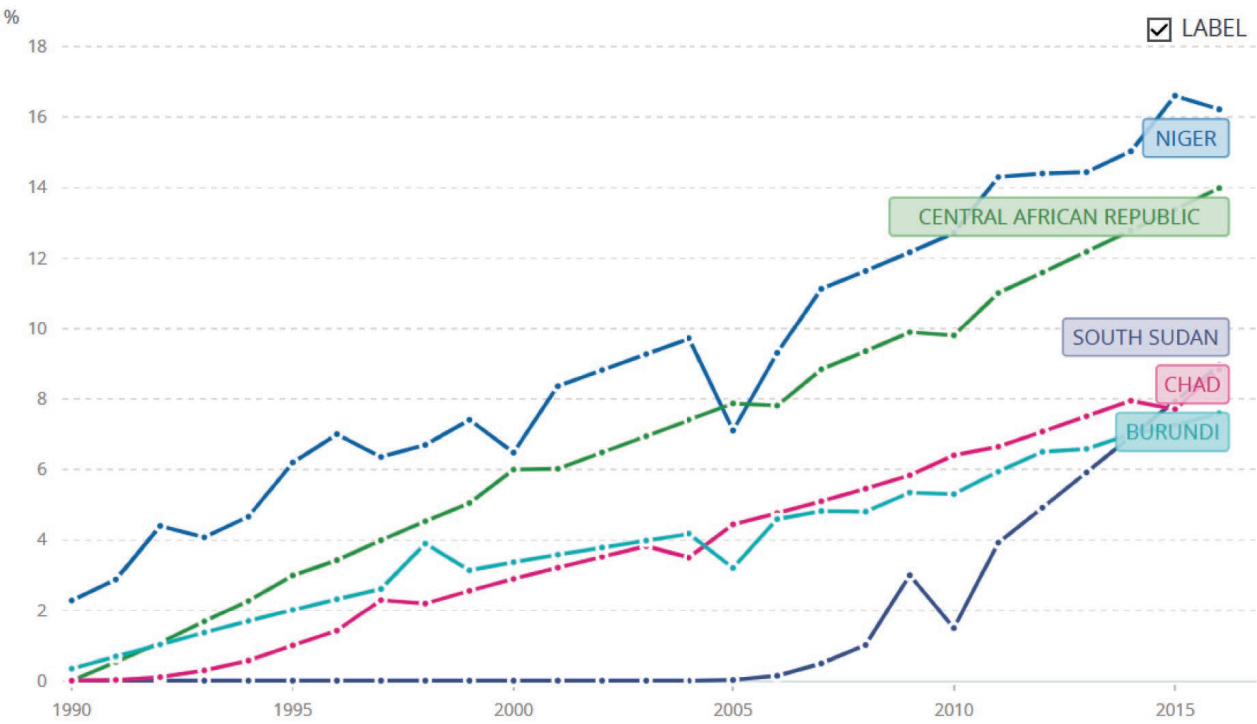

Fig. 4. Access to electricity in five least developed countries according to the HDI Index (\% of population)

Source: [World Bank Data (a)].

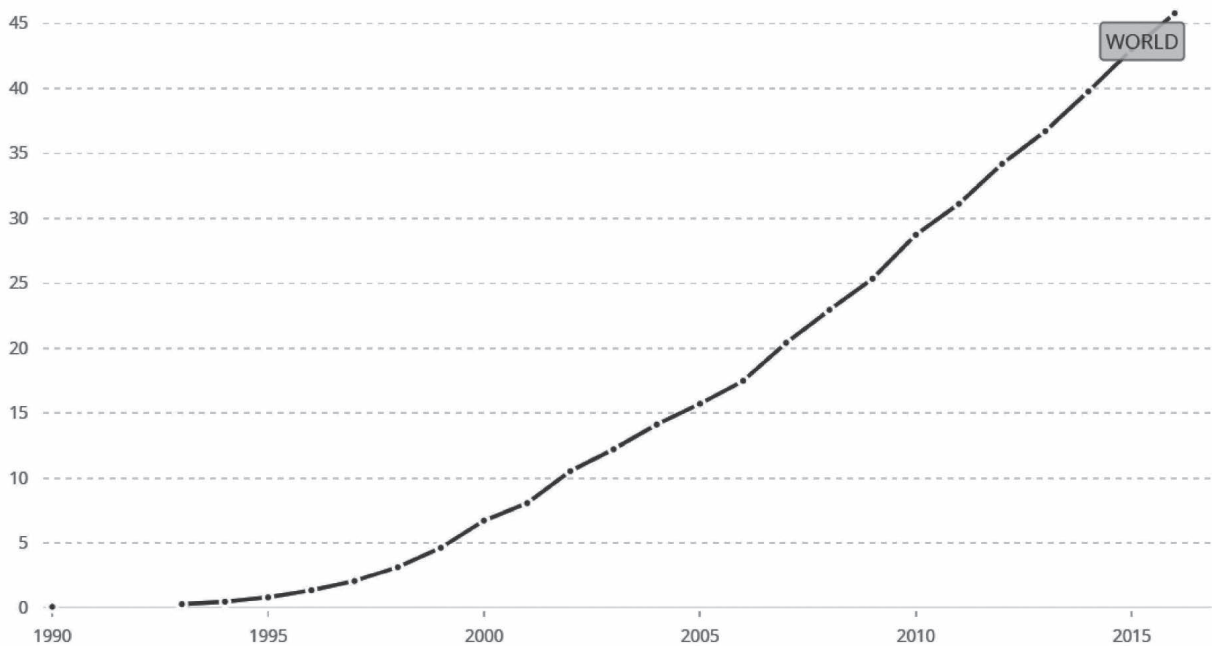

Fig. 5. Share of Internet users ( $\%$ of population)*

* The World Bank does not provide statistical data for this indicator for the least developed countries according to the HDI index (Burundi, Chad, Central African Republic, Niger, Burkina Faso). According to the Internet World Stats, 35.9\% of Africans have access to the Internet [Internet Users in Africa].

Source: [World Bank Data (b)]. 
process are: innovation itself, communication channels, time and the social system [Rodgers 1983]. E. Rodgers divides this process into five stages:

1. Knowledge (an individual becomes aware of the innovation and gains basic information about how it functions).

2. Persuasion (an individual shapes the attitude towards innovation - positive or negative).

3. Decision (an individual engages in activities aimed at adapting or rejecting innovation).

4. Implementation (an individual puts an innovation into use).

5. Confirmation (an individual looks for the reinforcement of a previous decision; based on experience and observation, he or she may reverse it, as illustrated in the diagram below).

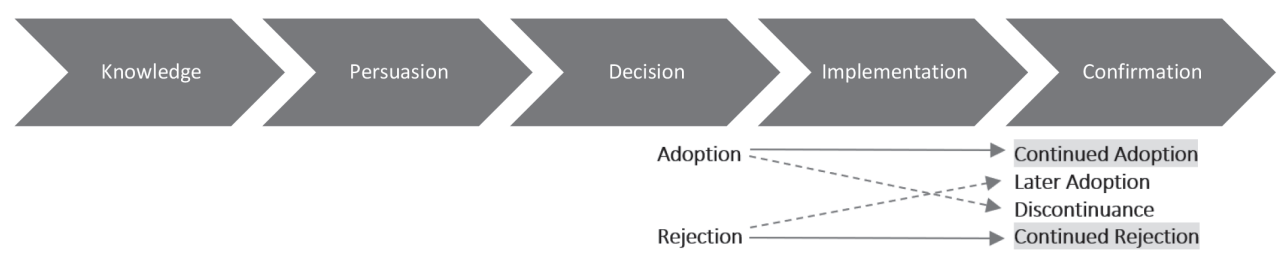

Fig. 6. Diffusion of innovation process

Source: own analysis based on [Rodgers 1983].

The decision of an individual (or of a decision-making entity) is made by calculating costs, benefits and the comparative advantage over existing solutions. The individual will adopt an innovation if he or she thinks it will increase his or her utility. The following factors also show a positive correlation with the rate of innovation diffusion and have a positive impact on the degree of its adaptation: compatibility with existing values, practices and experiences, the ability to test, and the observability of results. In turn, the complexity of innovation (the difficulty to understand and use an innovation) shows a negative correlation with the diffusion process [Rodgers 1983]. As a significant part of society does not understand the basics of the functioning of the blockchain technology, that last aspect may unfortunately have an unfavourable effect on its diffusion and may hamper this process. That is why providing ready-made tools may not be enough. Continuous learning and raising the users' awareness are crucial, even more so with respect to developing countries.

\section{Uncertainty, technological change and its consequences}

Uncertainty constitutes an inherent factor of technological change. The ex ante dimension of technical characteristics is its main and the most evident source that focuses on whether an innovation will work or not. While the technical aspect is undoubtedly crucial, there are also other important premises causing a high 
uncertainty of technological change. History knows many examples of how difficult and sometimes unpredictable the effects of technological change may be. When Alexander Bell invented the telephone, Western Union rejected the purchase of the patent for only USD 100,000, failing completely to anticipate the revolution that this invention would bring to the world. The nowadays omnipresent computer was originally intended to be used only for complicated mathematical calculations, and the radio only for navigational communication [Rosenberg 1996]. In 1939, the American New York Times reported on the successes of recent experiments, which testified the arrival of a new product: the television. However, as it was believed, "Television will never be a serious competitor for radio, because people must sit and keep their eyes glued on a screen; the average American family hasn't time for it" (quote from The New York Times after: [Rosenberg 2004]). The most important premises indicating a high uncertainty of technological changes as well as their effects are listed below [Rosenberg 1996; 2004].

Table 2. Uncertainty of technological changes

\begin{tabular}{|l|l|}
\hline \multicolumn{1}{|c|}{ Uncertainty premise } & \multicolumn{1}{|c|}{ Example } \\
\hline $\begin{array}{l}\text { the success of any innovation depends to a large } \\
\text { extent on market needs, rather than solely on the } \\
\text { possibilities of the technology. }\end{array}$ & $\begin{array}{l}\text { Boeing and Concorde airplanes - Concorde was } \\
\text { a major breakthrough in terms of technology, } \\
\text { but in economic terms it proved to be a failure. } \\
\text { In contrast, Boeing, while a moderate techno- } \\
\text { logical success, has become a great success in } \\
\text { economic terms. }\end{array}$ \\
\hline $\begin{array}{l}\text { The greatest innovations usually have their } \\
\text { origin in a very primitive form and go through } \\
\text { a very long process of improvements and modi- } \\
\text { fications. The uncertainty regarding the predic- } \\
\text { tion of the trajectory of changes translates into } \\
\text { the uncertainty of predicting the effects on the } \\
\text { economy. }\end{array}$ & $\begin{array}{l}\text { The first electric computer ENIAC had nearly } \\
\text { of a large room. The first plane took off in 1903, } \\
\text { hake it safe and reliable enough to serve socie- } \\
\text { ties as a means of transport. }\end{array}$ \\
\hline $\begin{array}{l}\text { The success of new technologies depends to } \\
\text { a large extent on the complementary sectors } \\
\text { necessary for the development of a specific in- } \\
\text { novation. }\end{array}$ & $\begin{array}{l}\text { The computer sector was revolutionised by the } \\
\text { later appearance of the transistor. }\end{array}$ \\
\hline $\begin{array}{l}\text { The most ground-breaking innovations have } \\
\text { not improved already-existing solutions; rather, } \\
\text { they have introduced completely new possibili- } \\
\text { ties. People mistakenly assume that a new tech- } \\
\text { nology can only be used to optimise already-exi- } \\
\text { sting processes. }\end{array}$ & $\begin{array}{l}\text { Laser, electricity. At the time when both were } \\
\text { invented, there was nothing that could be consi- }\end{array}$ \\
\hline $\begin{array}{l}\text { Innovation usually arises within a very narrow } \\
\text { field and aims to solve a specific problem. }\end{array}$ & $\begin{array}{l}\text { The steam engine was invented to pump out wa- } \\
\text { ter from mines. }\end{array}$ \\
\hline
\end{tabular}

Source: own analysis based on [Rosenberg 1970; 1974; 1996; 2004]. 
All premises proving the uncertainty of technological change can also be related to the current situation and deep changes specific to the Fourth Industrial Revolution. For example, it is highly doubtful that bitcoin in its present form will replace national currencies and become the basis of financial settlements. However, the possibilities offered by blockchain are enormous and new areas are still explored. Changes take time, and it is worth noting that only a decade has passed since the appearance of this technology. As S. Kline and N. Rosenberg [1986] claim, the greater the change, the greater the degree of uncertainty regarding both market reaction and effective implementation. According to K. Schwab [2017], the changes we are experiencing now are so profound that "from the perspective of human history, there has never been a time of greater promise or potential peril".

\section{Blockchain in developing countries}

According to many experts and international organisations, blockchain technology has the potential to mitigate the difficulties associated with the lack of solid infrastructure in developing countries. It can effectively contribute to the fight against poverty and become a tool for the development of an inclusive society, giving everyone (at a relatively low cost) access to basic services. In 1972, K. Arrow said that "it can be plausibly argued that much of economic backwardness in the world can be explained by the lack of mutual confidence". As mentioned before, mathematical algorithms allow for transactions without an intermediary, thus replacing trust and significantly reducing the costs incurred. Three areas where blockchain technology can be very important when it comes to improving quality of life and fighting poverty in developing countries are explored below. What is more, these are the areas where specific solutions and projects have started to appear.

\subsection{Financial sector and international capital flows}

Financial exclusion still constitutes a serious issue in developing countries. The fight against it is a key element in improving the quality of life of the population. The process of financial inclusion is based mainly on increasing access to the formal financial system, enabling societies to make transactions, raise loans and create savings accounts. Access to the financial system makes everyday life easier, helps to achieve long-term goals and to prepare for unexpected expenses. However, according to the World Bank statistics, close to one-third of adults 1.7 billion - do not have access to a bank account. Moreover, more than half of them state that the reason for this are the high costs or mismatch of services offered to low-income populations. Combating financial exclusion has become a priority for many international organisations and initiatives such as the United Nations (list of Sustainable Development Goals), the G20 Group (Digital Financial Integration Principles published in 2016), and the World Bank Group (recognition of financial 
inclusion as a key enabler to reducing extreme poverty and boosting prosperity and well-being) [Understanding Poverty...].

Blockchain overcomes many of the current challenges and limitations faced by the traditional banking sector. As it operates in a distributed network, where there is no single central server or database, there is no need to run complex and expensive infrastructure. This helps to reduce the costs that banks and financial service providers transfer to users in the form of transaction fees or accountant maintenance fees. The fragmentation and multiplicity of entities on the financial market cause inefficiencies in international transfers. There is no single global infrastructure that would allow for sending money, and this inefficiency is a barrier to economic development [Pisa, Juden 2017].

International transfers have to go through a series of intermediaries, both in the country initiating the transfer and the target country, which on average takes 3-5 days for one transaction. International capital flows are an important factor for the wellbeing of families and societies in developing countries. Unfortunately, the process of sending money, in addition to being relatively long, is often very expensive. In 2016, emigrants working abroad sent an estimated USD 430 billion to their families and relatives residing in their countries of origin (for comparison, this amount is nearly three times as high as the official aid to these countries) [Pisa, Juden 2017]. The average global cost of a transfer amounted in 2019 to $6.94 \%$. However, for some regions, especially the least developed, this amount significantly increases. For example, for the sub-Saharan Africa region, transaction costs were $9.25 \%$. According to the World Bank, reducing these costs by 5\% would save USD 16 billion a year [The World Bank].

Solutions using blockchain technology within financial services are now emerging. One of them, the BitSpark platform, is used to make transfers to Asian and African countries. It collects a fee of approximately 2 USD for transactions below 150 USD, and $1 \%$ of the transaction's value for larger amounts. Blockchain technology allows users to omit banking networks and intermediaries in traditional money remittance systems [Bitspark]. There are also other similar platforms enabling transfers to such countries as the Philippines, Singapore, Mexico, Rwanda, Ghana, Nigeria, Kenya or Zimbabwe, which collect only a small percentage of transactions. Some of them operate in the business-to-business system (e.g. BitPesa), reducing the cost of remittances for small enterprises and suppliers and therefore boosting entrepreneurship [Money Transfer].

\subsection{Property rights and certification}

In many developing countries, land grabbing continues to be a serious challenge. The process of combating this phenomenon is effectively hampered by a high level of corruption and unstable and untrustworthy institutions ${ }^{5}$. It allows criminal groups to

${ }^{5}$ Developing countries are perceived as countries with a very high level of corruption. According to the 2018 CPI Index (the Index measures the perception of corruption in individual countries), the 
manipulate land registry documentation. Land is a very important factor of production in developing countries, primarily in rural areas. Many countries, however, do not have a transparent system that would register land ownership. According to data, only $30 \%$ of the world's population has regally registered rights to their lands [World Bank]. In rural areas in Africa, this percentage is much smaller and amounts to about $10 \%$ [Pisa, Juden 2017]. What is more, farmers with small properties are illegally thrown out of their lands, being often deprived of their only source of income.

Ledgers based on blockchain technology are non-modifiable. Every change made in the network is visible to all its users. Modifying the information recorded in the ledger would require large amounts of computing power, making this type of manipulation practically impossible ${ }^{6}$.

Blockchain technology also helps to certify goods for which authenticity and origin are extremely important. For example, the company Everledger deals with diamond certification. All entities involved in the mining and selling of these precious stones use a distributed database, in which each diamond has an assigned code (a unique ID containing a total of 40 different features, such as the method of cutting, carats or colour) and high-quality photos featuring the serial number of the diamond. Subsequently, this information is uploaded to the registry and secured using the hash function. This prevents manipulation in databases and further supports the fight against illegal trade and mining of diamonds in war zones [Volpicelli 2017].

\subsection{Humanitarian aid}

Blockchain technology can also improve humanitarian aid. Fraud, discrimination and mismanagement deter a large part of the funds intended for reducing poverty, including improving education and health care.

In November 2017, the first Humanitarian Blockchain Summit was organised by Fordham University in cooperation with the United Nations (with the second edition being held in December 2018). During the conference, attention was focused on pilot projects using blockchain technology for humanitarian actions and for the implementation of the Sustainable Development Goals. It was emphasized that blockchain had an enormous potential in improving a lot of processes within the framework of transferring funds to the victims of natural disasters, coordinating deliveries or making humanitarian projects more gender-inclusive [Humanitarian Blockchain Summit].

At the beginning of 2017, the United Nations' World Food Program launched the first phase of the Building Blocks project, based on blockchain, with the aim to

countries with the highest level of corruption are: Somalia, Syria, South Sudan, Yemen, North Korea, Sudan, Guinea Bissau, Equatorial Guinea, Afghanistan and Libya. 5 out of 10 countries with the highest level of corruption represent Sub-Saharan Africa region [Corruption Perception...].

${ }^{6}$ The change in the first block entails the need to modify and recalculate all subsequent blocks. The system is secure as long as the computing power of honest nodes is greater than the computing power of attacking nodes [Nakamoto 2008]. 
help refugees staying in the Azraq camp in Jordan. The project website promotes blockchain as means of changing the way humanitarian agencies provide help. The goal of Building Blocks is to speed up transactions, lower their costs and increase security. What is more, the agency keeps a record of each transaction, and sensitive data does not pass through any intermediary [Building Blocks]. Blockchain-based solutions enable actors involved in humanitarian aid (i.e. donors, beneficiaries, partners and auditors) to track information on the progress of projects and the exact flow of funds. According to the agency's predictions, the use of this technology may also accelerate aid for disaster-stricken areas where banks and ATMs do not function. An interesting application is the Usizo crowdfunding platform, operating in South Africa, which allows users to cover electricity bills for African schools. Donors can track how much energy the school uses and calculate the amount of electricity that can be purchased with their donation [Usizo].

\section{Conclusions}

Technological change, which is a critical driver of long-term economic growth, constitutes an extremely complex phenomenon. As N. Rosenberg [1996] postulated, "New technologies are unrealized potentials that may take a very large number of eventual shapes". The success of these changes depends on a wide and complex context, which is the social environment where the incentives necessary for creating and implementing innovations are generated. The rate of the diffusion of a given technology, the effectiveness of public policies, and the process related to the learning of society are also highly important factors. The transfer of technology itself is not sufficient to cope with the issue of the poorest countries. The optimal development path for some countries is not the same as for others, and economic growth has never been an ordinary replication process [Rosenberg 1970].

Developing countries should not disregard the potential of blockchain technology, which can solve a lot of current problems and provide access to previously unreachable services at a relatively low cost (both implementation and subsequent maintenance cost).

It is necessary to understand new phenomena and concepts and to redefine the way of thinking, as without it, no change is possible. Undoubtedly, the number of ongoing projects run by international organisations as well as private companies is a good sign of the implementation of blockchain technology. This process, in order to be successful, needs a lot of long-term case studies that would address specific needs and confirm the positive impact on societies and on the economies of developing countries. 


\section{References}

Arrow K., 1972, Gifts and exchanges, Philosophy and Public Affairs, no. 1, pp. 343-362.

Bitspark, https://bitspark.io, date of access: 15.04.2019.

Blockchain Charts, https://blockchain.info/charts, date of access: 15.04.2019.

Building Blocks, http://innovation.wfp.org/project/building-blocks, date of access: 12.04.2019.

Corruption Perception Index, https://www.transparency.org/cpi2018, date of access: 14.04.2019.

EU Blockchain Observatory and Forum, Digital Single Market, https://ec.europa.eu/digital-single-market/en/eu-blockchain-observatory-and-forum, date of access: 14.04.2019.

European Parliament, Blockchain: a forward-looking trade policy, http://www.europarl.europa.eu/doceo/document/B-8-2018-0397_EN.html, date of access: 14.04.2019.

Fanning K., Centers D., 2016, Blockchain and its coming impact on financial services, The Journal of Corporate Accounting \& Finance, no. 27(5).

Humanitarian Blockchain Summit, https://www.fordham.edu/info/27346/humanitarian_blockchain_ summit, date of access: 14.04.2019.

Iansiti M., Lakhani K., 2017, The truth about blockchain, Harvard Business Review, January-February, 2017 issue.

Internet Users in Africa, March 31, 2019, http://www.internetworldstats.com/stats1.htm, date of access: 15.04.2019.

Kelly J., 2017, Top Banks and R3 Build Blockchain-Based Payments System, https://www.reuters. com/article/us-banks-blockchain-r3/top-banks-and-r3-build-blockchain-based-payments-systemidUSKBN1D00ZB, date of access: 15.04.2019.

Kline S., Rosenberg N., 1986, An Overview of Innovation, [in:] Landau R., Rosenberg N. (eds.), The Positive Sum Strategy: Harnessing Technology for Economic Growth, National Academy of Sciences, Washington, D.C.

Klinger B., Szczepański J., 2017, Blockchain - historia, cechy i główne obszary zastosowań, Człowiek w Cyberprzestrzeni, nr 1/2017.

Korjus K., 2017, Welcome to the Blockchain Nation, https://medium.com/e-residency-blog/welcometo-the-blockchain-nation-5d9b46c06fd4, date of access: 14.04.2019.

Money Transfer Companies Using Blockchain Technology, https://medium.com/@gomedici/11-money-transfer-companies-using-blockchain-technology-572ca2061be9, date of access: 15.04.2019.

Nakamoto S., 2008, Bitcoin: A Peer-to-Peer Electronic Cash System, White Paper.

Pilkington M., 2015, Blockchain Technology: Principles and Applications, Research Handbook on Digital Transformations, https://pdfs.semanticscholar.org/e31c/a71621e1402a46ac2c1afb2eba9a7061d139.pdf, date of access: 10.04.2019.

Pisa M., Juden M., 2017, Blockchain and Economic Development: Hype vs. Reality, Policy Paper, Center for Global Development Washington, D.C.

Rodgers E., 1983, Diffusion of Innovations, The Free Press, New York.

Rosati P., Nair B., Lynn, T., 2016, Bitcoin vs Blockchain: The Role of Trust in Disrupting Financial Services, Conference Paper, $7^{\text {th }}$ European Business Research Conference 15-16 December, University of Roma Tre.

Rosenberg N., 1970, Economic development and the transfer of technology: Some historical perspectives, Technology and Culture, vol. 11, no. 4.

Rosenberg N., 1974, Science, innovation, and economic growth, The Economic Journal, vol. 84, p. 333.

Rosenberg N., 1996, Uncertainty and technological change, Conference Series [Proceedings], vol. 40, Junuary issue.

Rosenberg N., 2004, Innovation and Economic Growth, OECD.

Schwab K., 2017, The Fourth Industrial Revolution, Penguin Random House, New York.

Swan M., 2015, Blockchain - Blueprint for a New Economy, O'Reilly Media, Sebastapol. 
Tapscott D., Tapscott A., 2016, Blockchain Revolution: How the Technology behind Bitcoin is Changing Money, Business, and the World, Penguin Random House, New York.

The World Bank, Remittance Prices Worldwide, https://remittanceprices.worldbank.org//sites/default/ files/rpw_report_march_2019.pdf, date of access: 14.04.2019.

Understanding Poverty, Financial Inclusion, http:/www.worldbank.org/en/topic/financialinclusion/ overview, date of access: 15.04.2019.

Usizo, http://secret.usizo.org, date of access: 12.04.2019.

Volpicelli G., 2017, How the blockchain is helping stop the spread of conflict diamonds, http://www. wired.co.uk/article/blockchain-conflict-diamonds-everledger, date of access: 15.04.2019.

World Bank, Why Strengthening Land Rights Strengthens Development, https://blogs.worldbank.org/ voices/why-strengthening-land-rights-strengthens-development, date of access: 14.04.2019.

World Bank Data (a), https://data.worldbank.org/indicator/eg.elc.accs.zs, date of access: 10.04.2019.

World Bank Data (b), https://data.worldbank.org/indicator/IT.NET.USER.ZS, date of access: 10.04.2019.

World Economic Forum Global Agenda, Top 10 Emerging Technologies of 2016, http://www3.weforum. org/docs/GAC16_Top10_Emerging_Technologies_2016_report.pdf, date of access: 15.04.2019.

Zheng Z., Xie S., Dai H., 2017, Blockchain challenges and opportunities, International Journal of Web and Grid Services (IJWGS), vol. 14, no. 4. 